\title{
Fordism to Free Trade: An Explanation of the Shift Towards Globalisation
}

\author{
Colin McLeay
}

\section{ABOUT THE AUTHOR}

Colin McLeay teaches geography at Tauranga University College of the University of Waikato. His particular interests are in cultural production, globalisation, and urban entrepreneurialism.
New Zealanders tuning into television news on the evening of December 1, 1999, were confronted with images of demonstrators in downtown Seattle breaking windows, vandalizing vehicles, and setting fires. As police sought to control rioters, arresting hundreds of demonstrators, television viewers were informed that the scenes in Seattle were reminiscent of the civil rights and anti-war protests that shook the United States in the 1960s. While American civil rights and anti-war protests were responses to domestic policy initiatives, the demonstrations in Seattle were organised by individuals from numerous countries, united in their suspicion of global free trade agendas.

The numbers of demonstrators in Seattle, and their willingness to face arrest, highlights the passion that can be aroused when 'free trade' and 'globalisation' are being debated. Clearly, different responses to socioeconomic change reflect different perspectives on the positive and/or negative impacts of globalisation. The nature of individual reactions to globalisation are influenced by information sourced from print and audio-visual media, from public meetings and discussions, and from conversations held in the workplace and at home. These 'sites' of information express particular accounts of globalisation and may be positioned on a continuum between being supportive or critical, abridged or detailed, balanced or biased, abstract or emotional. In general, it may be argued that media outlets or individuals will present that information which best supports their particular position.

The purpose of this article is to move beyond overtly subjective or emotional accounts of globalisation, providing an historical overview of events that lead to the emergence of processes of globalisation. The 'global shifts' that have affected virtually all industrialised economies since the 1970 s may be traced to a "crisis of capitalism" that originated from the breakdown of "Fordist regimes of accumulation" (Clarke, 1992:13). As such, the 'story' presented below highlights the economic imperatives that underpin the development of processes of globalisation; while global shifts have had a profound impact on cultural codes and commodities, it is widely agreed that such transformations were largely responses to economic 
developments. Beginning with an explanation of 'Fordism', this article accounts for the development of the 'long boom' in the 1950s and 1960s, explores the economic decline that characterised the 1970s, and discusses the rise of 'global' networks of production and consumption in the 1980s and 1990s.

\section{The meaning of Fordism}

The origins of the term 'Fordism' may be traced to the methods of mass production introduced by the American industrialist Henry Ford and developed by the Ford Motor Company beginning in the second decade of the twentieth century. The organisational regimes and labour processes implemented by Ford were based on the fragmentation of production tasks, an approach most clearly expressed through the assembly line. The assembly line reduced labour time and costs by separating production processes from assembly functions, and by allowing for the mass production of standardised components. Workers, however, did not approve of the assembly line system and resisted its implementation by interrupting production, sabotaging quality controls, and taking extended sick leave. In order to placate his workers, Ford shortened the working day to eight hours and increased daily wages to five dollars. In addition to reducing labour problems and increasing productivity, the eight-hour, five-dollar-day created conditions in which workers had sufficient income and leisure time to consume the mass-produced goods being manufactured on assembly lines (Harvey, 1989:126).

By the late 1920s many firms in the United States and Europe had followed the lead set by the Ford Motor Company, introducing mass production manufacturing techniques and enjoying increased profits. In the 1930s, however, low business activity and increased competition associated with the Great Depression reduced profit margins. In response to these conditions, employers removed the five-dollarsa-day wage. As wages were cut workers could no longer buy as many goods as previously, leading to a decline in demand. Falling demand further reduced company profitability and exacerbated recessionary trends. In order to stimulate economic activity, the United States government, led by President Roosevelt, implemented a series of 'New Deal' policies. Introduced in 1933, the New Deal policies sought to regulate economic activity and extend the state's responsibility for the provision of welfare services. Before the New Deal policies could be effectively implemented, however, World War Two intervened and workers and capitalists agreed to set aside their differences in favour of a 'patriotic' effort to mass produce military equipment.

\section{The post-war long boom}

Immediately after the end of the Second World War governments in industrialised nations, such as the
United States of America, Britain, Australia, New Zealand, Canada, implemented a series of wide-ranging policy interventions designed to increase employment and aid industrial reconstruction. While the specific forms of intervention varied greatly, the majority of industrialised nations achieved stable economic growth and a rising material living standard through adopting models of Keynesian economic management (Harvey, 1989:135). Based on the theories of the British economist John Maynard Keynes, Keynesian economic policies relied on the state manipulating the economy to maintain levels of investment and overall demand for goods and services (Fagan and Webber, 1994:124). For example, by varying tax rates, interest rates and public expenditure governments aimed to control inflation, maintain high employment, and reduce business fluctuations.

The success of Keynesian state interventions in the 1950s and 1960s relied upon the support of company owners (capitalists) and workers. Indeed, the FordistKeynesian configuration of mass production practices and state policies that characterised the post-war long boom was based on an 'uneasy truce' between governments, capitalists, and workers. In the majority of countries, this 'truce' had corporate owners agreeing to investment programmes that would increase productivity and the living standards of workers; national governments implementing policies designed to increase levels of employment and provide welfare support for citizens; and, workers accepting wage rises in payment for adhering to rigid working practices and non-strike conditions. An important outcome of these wage agreements was that sufficient income was distributed to workers to support the consumption of industrial products on a mass scale, a feature that guaranteed that demand would keep pace with supply (Lipietz, 1982:35). The success of the Fordist-Keynesian compromise was such that industrialised nations experienced almost 20 years of economic growth and low unemployment. This period, from the early 1950 s to the early 1970s, is the so-called 'long boom'.

The international spread of Fordist-Keynesian agreements in the years following World War Two was based on the manufacture of several "core" products in large manufacturing districts.

Cars, ship-building, and transport equipment, steel, petrochemicals, rubber, consumer electrical goods, and construction became the propulsive engines of economic growth, focused on a series of grand production regions in the world economy - the Midwest of the United States, the Ruhr-Rhinelands [in Germany], the West Midlands of Britain, the Tokyo-Yokohama production region (Harvey, 1989:132).

The principal means by which mass production techniques were integrated internationally was through the activities of transnational corporations (TNCs), exemplified by such companies as Ford (motor vehicle 
manufacturing, with a head office in the United States), Philip Morris (tobacco and foodstuffs, United States), Siemens (electronics, Germany), Nestlé (food, Switzerland) and ICI (industrial chemicals, United Kingdom). While large companies had been involved in international trade since the mid-nineteenth century, TNCs were unique in that they relied on intra-firm trade, whereby products were transferred from one branch or plant of a corporation to another across international boundaries (Fagan and Webber, 1994:15). The most obvious expression of intra-firm trade was through large Anglo-American firms using mines and plantations in South America and Africa to supply raw materials for products manufactured in the United States, Europe or the United Kingdom.

These trans-national activities ensured that TNCs were central to the rapid acceleration of international production during the long boom (Dicken, 1992:4). Furthermore, as TNCs expanded their international operations in the 1950s and 1960s they came to own and operate increasing numbers of farms and mines in 'peripheral' countries in Africa, Asia and South America. The ability of TNCs to maintain international trading networks was helped by developments in transport and communication technologies. For example, the development of commercial jet aircraft, the simplification of cargo transfer, and advances in communication technology revolutionised the ability of TNCs to operate over vast geographical distances (Dicken, 1992:108).

\section{The end of the long boom}

Despite the ability of TNCs to balance international production and trade networks, by the early 1970s many capitalist producers and national-economies had begun to experience a slowdown in economic growth. While signs of the impending 'crisis of Fordism' were evident several years earlier, it took the collapse of the Bretton Woods Agreement in 1971 and the effects of the 'oil shock' of 1973 to set in motion a whole set of processes that undermined the Fordist-Keynesian compromise and the success of the 'long boom' (Harvey, 1989:145). The Bretton Woods Agreement was formulated at a meeting between officials from the United States, Britain and Canada in 1944. Named after the North American town where the meeting was held, the Bretton Woods Agreement was designed to facilitate post-war reconstruction by instituting international conditions covering trade relationships and financial dealings.

One of the regulations imposed by the Bretton Woods Agreement ensured that the United States government would convert overseas holdings of United States dollars to gold at a fixed rate of \$US35 per ounce of gold. This meant that foreign governments and businesses could rely on currency stability and, therefore, predictability in terms of the international pricing of goods. The Bretton Woods Agrecment worked well during the 1950s and early 1960s, "the golden age of capitalism in the developed world" (Corbridge and Thrift, 1994:7), a period during which the United States maintained a budget surplus. By the late 1960s, however, expenditure associated with the Cold War with the Soviet Union, the war in Vietnam, and re-armament programmes in Western Europe had turned the United States budget surplus into a deficit.

Despite holding a budget deficit, as long as overseas governments with held from exchanging their financial reserves for gold, the United States was able to continue to guarantee the gold reserve that underpinned international currency stability. As 'foreign' economies accumulated increasingly large currency reserves, and the American balance of payments situation worsened, however, it became obvious in the late 1960s that overseas funds would eventually dwarf the size of the United States gold reserves (Strange, 1994). With the possibility that foreign governments would demand the United States swap their currency reserves for American gold, the Nixon administration decided to end the role of the United States as the 'world's banker'. With the United States dollar no longer backed by gold, its value was determined according to international confidence in its trading worth.

Given that the United States dollar had provided a stable benchmark for other currencies for twenty years, the removal of gold reserve had enormous impacts (Corbridge and Thrift, 1994). For example, governments that had relied on the security provided by the American gold reserve, of which there were many, found that, like America, their currency value fluctuated depending on international confidence. For individuals or companies involved in international trade, currency instability ensured there was price instability, meaning there was no guarantee that the amount of goods bought for " $x$ " dollars one week would cost the same the next week. Such price fluctuations increased competition and forced many traders out of business.

Two years after the United States abandoned the Bretton Woods Agreement, the Organisation of Petroleum Exporting Countries (OPEC) increased prices for oil. Between October 1973 and January 1974, OPEC, a powerful cartel of oil producers headed by Saudi Arabia, Iran, Iraq and Kuwait, raised the price of oil. Implemented in response to the Arab Israeli War, these price rises led to a panic in oil markets. As oil and oil-based products were a central input into heavy industries, increases in production costs stemming from oil price rises had a significant impact on corporate profit. The productivity and profitability of industrial producers was also hindered by increasing wage costs. The high demand for labour that had accompanied post-war policies of full employment had 
strengthened trade unions, and worker organisations used theirgrowing power to obtain large wage increases.

While commodity price rises provided a short-term panacea for rising material and labour costs, one longterm result of this strategy was an increase in levels of inflation. Increasing inflation generally served to reduce company profits by raising labour costs. As profits continued to fall and labour costs continued to rise, industrialised nations experienced widespread depression in both capital-intensive industries (e.g. steel, shipbuilding, vehicles, appliances) and labourintensive industries (e.g. textiles, clothing, footwear) (Knox and Agnew, 1994:210).

\section{Responses to recession}

In order to retain profitability during the recession of the 1970 s some TNCs began to shift operations away from core to peripheral countries. By locating manufacturing facilities in so-called 'Newly Industrialising Countries' (NICs) in East and South East Asia (South Korea, Hong Kong, Singapore, Taiwan, Malaysia, Thailand), Latin America (Brazil, Mexico), and Southern Europe (Spain, Portugal, Greece), TNCs were able to produce manufactured components and commodities relatively cheaply. These goods were then exported back to core markets, mainly the United States and the United Kingdom.

The success of the move to the periphery relied on several inter-related factors: an increase in automation that facilitated the employment of lowcost semi- or un-skilled workers; production fragmentation that enabled components to be manufactured in the periphery and assembled into a 'whole' in the core of industrialised nations; and, the rapid transit of goods and information between dispersed localities (Fagan and Webber, 1994:37). While expansion into peripheral nations seemed to offer a solution to the profitability crisis facing TNCs, it did not take long for production bases in core economies to be undermined by imports sourced from NICs. The export successes of NICs stemmed from their adoption of mass production techniques but not the labour relations or national economic policies that had regulated production and consumption in the core. Without competitive constraints imposed by wage bargains with labour and state sanctioned stability in both products and prices, NICs were able to build their economies around exports to mass markets elsewhere (Schoenberger, 1988).

As NICs increased their status as industrial producers during the 1970 s so the range of products they manufactured broadened. 'The major growth in exports [from NICs] after the mid-1970s occurred in traditional products that in the past were associated with the industrial countries of Western Europe and
North America: electrical and non-electrical machinery, transport equipment, chemicals, and iron and steel' (Fagan and Webber, 1994:22).

\section{Globalshifts}

Faced with increasing competition from NICs, costs associated with the employment of unionised labour, and taxation regimes enforced to maintain domestic welfare programmes, corporations in core economies began to reorganise their production systems. The result of industrial reorganisation was the deindustrialisation of the core economies' (Knox and Agnew, 1994:208), expressed most obviously through decline in those sectors that had underpinned economic growth in the 1950s and 1960s, such as shipbuilding, and textile and motor vehicle manufacture. Dicken (1992:429-35) suggests that the most significant influences on deindustrialisation were a worldwide recession that increased levels of unemployment and technological changes that tended to be labour-saving rather than job-creating.

In a 'global shift' that was designed to alleviate the financial impacts of deindustrialisation in the core, many firms established overseas branch plants or international subcontracting alliances. Such linkages furthered deindustrialisation in the core, while also signalling a shift from 'international' to 'global' networks of trade and exchange (Probert, 1993).

'Internationalisation' refers simply to the increasing spread of economic activities across national boundaries; as such it is not a new phenomenon. 'Globalisation' of economic activity is qualitatively different. It is a more advanced and complex form of internationalisation which implies a degree of functional integration between internationally dispersed economic activities. Globalisation is a much more recent phenomenon than internationalisation (Dicken, 1992:1).

Such 'functional integration' defines the way in which corporations maintain strategies that are sensitive to local market conditions and yet are also able to function as a globally integrated unit. Using the automobile industry as an example, this 'global localisation' has expressed itself in two obvious ways. Firstly, rather than establishing complete manufacturing and assembly plants in numerous individual countries, large vehicle manufacturers have developed a network of numerous specialist manufacturing sites that supply a few centralised assembly plants. For example, Figure 1 shows the complex component sourcing network the Ford Motor Company has for the Ford Escort model that is assembled in England.

Secondly, firms will mix their globally sourced vehicle components in different ways to suit the demands of particular markets. For example, Mair (1997) reports 
new zealand journal of Geography april 2000,13

\begin{tabular}{|c|c|}
\hline $\begin{array}{l}\text { SOURCE } \\
\text { COUNTRY }\end{array}$ & COMPONENT \\
\hline United Kingdom & $\begin{array}{l}\text { rocker arm, clutch, ignition, exhaust, oil pump, distributor, cylinder bolt, cylinder } \\
\text { head, flywheel ring gear, heater, speedometer, battery, read wheel spindle, intake } \\
\text { manifold, fuel tank, switches, lamps, front disc, steering wheel, steering column, } \\
\text { glass weatherstrips, locks }\end{array}$ \\
\hline France & $\begin{array}{l}\text { alternator, cylinder head, master cylinder, brakes, underbody coating, weatherstrips, } \\
\text { clutch release bearings, steering shaft \& joints, seat pads \& frames, transmission } \\
\text { cases, clutch cases, tyres, suspension bushes, ventilation units, heater, hose clamps, } \\
\text { sealers, hardware }\end{array}$ \\
\hline Canada & glass, radio \\
\hline U.S.A. & wheel nuts, hydraulic tappet, glass \\
\hline Spain & $\begin{array}{l}\text { wiring harness, radiator \& heaterhoses, fork clutch release, air filter, battery, } \\
\text { mirrors }\end{array}$ \\
\hline Italy & cylinder head, carburettor, glass, lamps, defroster grills \\
\hline Switzerland & underbody coating, speedometer gears \\
\hline Japan & starter, alternator, cone \& rollerbearings, windscreen washerpump \\
\hline West Germany & $\begin{array}{l}\text { locks, pistons, exhaust, ignition, switches, front disc, distributor, weatherstrips, } \\
\text { rocker arm, speedometer, fuel tank, cylinder bolt, cylinder head gasket, front wheel } \\
\text { knuckles, read wheel spiundle, transmission cases, clutch cases, clutch, steering } \\
\text { column, battery, glass }\end{array}$ \\
\hline Netherlands & tyres, paints, hardware \\
\hline Sweden & hose clamps, cylinder bolt, exhaust down pipes, pressings, hardware \\
\hline Norway & exhaust flanges, tyres \\
\hline
\end{tabular}

Figure 1: The component sourcing network for the Ford Escort in Europe (Source: Dicken, 1992, 301 ).

that Honda motor cars sold in America may share engines and transmissions with Japanese models, but differ in interior aesthetics. Or a European model may share everything but handling components and aesthetics with a Japanese model. Mair (1997:71) notes that the key issue for the Honda Motor Company is "to put all the pieces together for each local market in a way that both meets the requirements in that market ... and also permits economies of scale and acceptance. of the product in other Honda regions".

The 'functional integration' that is central to globalisation has created a new form of corporate entity.

The most recent, quite newly emerging for of spatial structure is that of the 'global corporation' - a massively multinationalised entity ... which spans a variety of sectors of production(both manufacturing and services) and which is organised not so much from a centre in one country from which the tentacles of power spread out to others, but on a truly international basis, with a global profits strategy, a view of a world divided for this purpose into regions, each with their own operational headquarters, and with ... no particular country called 'home' (Massey, 1994:159).

While TNCs and/or global corporations had a key role in creating and advancing global processes, national governments contributed by introducing policies that undermined existing social welfare and labour market conditions. As Knox and Agnew (1994) explain, electoral victories by right-of-centre political parties in many industrialised economies during the 1970s and 1980s were associated

with an ideological stance based on the belief that the welfare state had not only generated unreasonably high levels of taxation, budget deficits, disincentives to work and save, and a bloated class of unproductive workers, but also that it may have fostered 'soft' attitudes towards 'problem' groups in society (Knox and Agnew, 1994:237-238).

While the style and time-frame of the retrenchment that characterised this 'new conservatism' differed from country to country, most state sector restructuring programmes implemented in the 1970s and 1980s relied on the privatisation of public services (health, housing, education) and spending cuts to unemployment and superannuation benefits (Britton, Le Heron and Pawson, 1992). As part of these programmes of restructuring national governments re-regulated border control policies, effectively 'opening up' their economies to increased flows of off-shore goods, services, and investment funds.

\section{Conclusion}

In seeking to open their economies to overseas investors, thus creating a 'global market', national governments were helped by large global corporations. Rather than being monolithic, governments and businesses exist because of the actions and activities of a host of individuals, be they politicians, bureaucrats, executives and labourers. As with any group of people, 
regardless of how coherent they appear to 'outsiders', these individuals all have particular ideas and emotions, thoughts and passions. Given the diversity inherent in any group or community, it is difficult to make assumptions about the exact path globalisation will take in the future. Indeed, as events in Seattle showed, the widespread acceptance of theinevitably of globalisation is not assured. With historic evidence showing that globalisation is the most recent stage in the ongoing capitalist characteristic of competition and profit seeking, it would be a very brave person who predicted a long future for the current modes of globalisation. Given events in Seattle in late 1999, perhaps the only accurate prediction that can be made is that debates about the nature of globalisation will be passionate, political and, more often than not, polarising.

\section{References}

Britton, S., Le Heron, R. and Pawson, E. (eds) 1992: Changing Places in New Zealand: A Geography of Restructuring, New Zealand Geographical Society, Christchurch.

Clarke, S. 1992: What in the F-'s name is Fordism, in Gilbert, N., Burrows, R. and Pollert, A. (eds), Fordism and Flexibility, St. Martin's Press, New York, 13-30.

Corbridge, S. and Thrift, N. 1994: Money, power and space: introduction and overview, in Corbridge, S., Martin, R. and Thrift, N. (eds), Money, Power and Space, Blackwell, Oxford and Cambridge, 1-25.

Dicken, P. 1992: Global Shift: The Incernationalisation of Economic Activity, 2nd edition, Paul Chapman Publishing, London.

Fagan, R. and Webber, M. 1994: Global Restructuring: The Australian Experience, Oxford University Press, Melbourne.

Harvey, D. 1989: The Condition of Postmodernity: An Enquiry into the Origins of Cultural Change, Blackwell, Oxford.

Knox, P. and Agnew, J. 1994: The Geography of the World Economy, 2nd edition, Edward Arnold, London.

Lipietz, A. 1982: Towards global Fordism?, New Left Review, 132, 33-47.

Mair, A. 1997: Strategic localisation: the myth of the postnational enterprise, in Cox, K. (ed.), Spaces of Globalisation: Reasserting che Power of the Local, The Guilford Press, New York, 64-88.

Massey, D. 1994: A place called home?, in Space, Place and Gender, Polity Press, London, 157-173.

Probert, B. 1993: Restructuring and globalisation: what do they mean?, Arena Magazine, April/May, 18-22.

Schoenberger, E. 1988: From Fordism to flexible accumulation: technology, competitive strategies, and international location, Environment and Planning D: Society and Space, 6(3), 245-262.

Strange, S. 1994: From Bretton Woods to the Casino Economy, in Corbridge, S., Martin, R. and Thrift, N. (eds.), Money, Power and Space, Blackwell, Oxford and Cambridge, $49-62$. 